\title{
RESENHA
}

\section{HARVEY, David. Rebel cities. New York: Verso books, 2012.}

\section{A cidade como protagonista}

David Harvey tem sido uma referência constante e onipresente na Geografia e em outras ciências sociais nos últimos anos, e seu mais novo livro Rebel Cities vem se unir a um conjunto de trabalhos recentes que formam um período bastante fecundo do autor. O livro consiste em uma reunião de artigos publicados nos anos recentes temáticas, embora um tanto díspares, orientam-se por uma preocupação em desvendar a complexa relação entre crises econômicas, urbanização e mudança social no capitalismo atual. Harvey retorna, portanto, a questões que sempre o preocuparam, com a diferença de que o autor adota, em certos momentos, um estilo bem mais ensaístico do que o rigor acadêmico de trabalhos de fôlego como The limits to capital (1982) ou Justice, nature and the Geography of Differences (1996). Além disso, no livro, Harvey dá um destaque diferenciado à reflexão sobre as condições políticas e intelectuais associadas à construção de uma sociedade pós-capitalista, e coloca a cidade no centro das possibilidades atuais de transformação social radical. Antes de oferecer uma apreciação mais geral do livro, convém retomar alguns dos seus argumentos principais.

Nos primeiros dois capítulos do livro, Harvey recupera, à luz dos desdobramentos recentes da crise imobiliária americana, uma de suas proposições mais interessantes: a de que o processo de urbanização pode ter desempenhado, ao longo da história, o papel de solucionar, temporariamente, o problema das crises de excesso de acumulação a que o capitalismo sempre se mostrou propenso. $\mathrm{O}$ mecanismo que viabiliza essa solução é a convergência entre as instituições e regulações do Estado, de um lado, e o sistema de crédito, do outro, no sentido de estabelecer o contexto propício ao financiamento de investimentos no ambiente construído urbano. Esses investimentos absorvem capitais ociosos e mão 
de obra desocupada em projetos de longa duração, permitindo dar continuidade ao processo de acumulação.

Harvey sempre frisou, em seus trabalhos, que essa solução é incerta e prenhe de contradições: o ambiente construído de fato absorve volumes expressivos de capital, mas em algum ponto no futuro esses investimentos devem se mostrar produtivos, ou seja, devem se mostrar propícios ao aumento da produtividade do trabalho e, portanto, à produção de maisvalia relativa. Quando isso não ocorre, então eclodem crises de sobreacumulação cujo epicentro são, exatamente, esses investimentos materializados no ambiente construído urbano. É esse último cenário que Harvey explora com maior persistência na primeira parte de Rebel Cities. Em um dos capítulos mais instigantes do livro, Harvey sugere que o investimento especulativo no ambiente construído urbano teve uma centralidade muito maior do que até hoje se admitiu na eclosão de crises como a de 1929, a de 1973 e, evidentemente, a mais recente. Utilizando um artigo de dois economistas, Harvey aponta inclusive para uma correlação entre a proliferação de grandes projetos urbanos, como arranha-céus, e a iminência de crises econômicas de maior dimensão.

No terceiro capítulo, Harvey explora as possibilidades políticas que se abrem ao pensar a cidade e sua produção como um bem comum. Aqui, ele contrapõe a ideia de bem comum tanto no privado quanto no público. Enquanto que a esfera privada se origina em formas de cercamento e apropriação privada de bens coletivamente geridos/produzidos, o público, fruto da intervenção do Estado, ainda que possa servir de base para a produção/organização do comum, não equivale a esse último. $\mathrm{O}$ comum supõe, antes, a apropriação coletiva das condições sociais e ambientais de reprodução da vida dos grupos sociais, o que invoca necessariamente formas de organização política diferentes das que hoje preponderam. São essas novas formas de organização política que a esquerda costuma evocar, mas raramente discute a fundo, e que Harvey considera pertinente colocar em pauta, embora seja concisa a sua contribuição a essa discussão.

O quarto capítulo é uma versão reformulada do artigo "A arte da renda", já publicado no Brasil na coletânea "A produção capitalista do espaço". Aqui, Harvey examina as contradições da produção cultural no capitalismo, utilizando o conceito de renda de monopólio. Para Harvey, a necessidade que o capital possui de se proteger das formas mais implacáveis de concorrência o conduz a adotar estratégias de obtenção de rendimentos de monopólio mediante a apropriação e mercantilização de tradições culturais, expressões artísticas e manifestações simbólicas locais 
e regionais, que podem ser vendidas a preços de monopólio em virtude de sua suposta autenticidade e singularidade. Essas práticas permeiam, hoje, as estratégias de gestão das cidades em meio a um ambiente de crescente competição interurbana: produzir um "capital simbólico coletivo" e veiculá-lo mundialmente como base para obtenção de ganhos de monopólio emergiu, nitidamente, como o horizonte de muitas coalizões de classe, urbanas e regionais. A questão seria, para o autor, encontrar formas de resistir à mercantilização das tradições culturais, utilizando-as como substrato para movimentos políticos progressistas.

O quinto capítulo complementa em grande medida o terceiro, pois nele Harvey explora a miríade de condições intelectuais, políticas e sociais que possibilitam colocar a cidade no centro das lutas sociais por uma sociedade pós-capitalista. O cerne do problema reside em conceber as lutas procedentes do ambiente de trabalho como umbilicalmente entrelaçadas com aquelas que afloram nos bairros e comunidades da classe trabalhadora. Para forjar essa unidade entre os momentos da produção e da reprodução como fundamento de uma luta anticapitalista, Harvey entende que é preciso conceber a cidade como uma totalidade coletivamente produzida e, por conseguinte, suscetível de ser coletivamente apropriada e democraticamente administrada por aqueles que cotidianamente a reproduzem. É a cidade e a reivindicação de um direito à cidade - o direito de participar ativamente das decisões acerca do destino da cidade e das relações sociais nela travadas - que podem, para Harvey, soldar as separações que obstruem as lutas por uma sociedade mais justa.

O livro termina com duas análises de conjuntura, breves porém interessantes, sobre as revoltas ocorridas nas periferias de Londres em meados de 2011 e sobre o movimento Occupy Wall Street nos Estados Unidos, que conseguiu colocar em pauta a desigualdade social na sociedade americana, usando o slogan dos $99 \%$ contra os $1 \%$.

Como costuma acontecer com toda compilação, que reúne artigos escritos em contextos e com preocupações diferentes, Rebel cities é desigual. Ademais, se é possível discernir um fio condutor perpassando pela maior parte do livro, o capítulo 4 parece um tanto deslocado - o que reflete, em parte, o fato de ter sido escrito há bem mais tempo do que o restante dos artigos (no início da década passada) e, em parte, o fato de lidar com um tema que apenas tangencialmente se vincula às discussões nos outros capítulos. 
Um dos méritos de Harvey é que ele demonstra, em Rebel cities, ser um pensador que vem envidando esforços no sentido de, por um lado, acompanhar e interpretar os acontecimentos mais recentes à luz de conceitos desenvolvidos ao longo de quatro décadas de trabalho no campo da Geografia Radical; e, por outro, exibir um comprometimento sério e continuado com um projeto de transformação social, o que é, cada vez mais raro, nos dias de hoje. Rebel Cities é a expressão de um momento em que Harvey assume, cada vez mais, uma figura de intelectual público, com intervenções não apenas em universidades, mas em eventos políticos da esquerda, em programas de rádio e televisão e através da manutenção de um website com milhares de acessos na internet. Certamente, pode haver perdas nessa escolha: alguns lamentarão o fato de que Harvey não tem mais produzido novas categorias e conceitos que possam servir de ferramentas para interpretar fenômenos novos, o que é, em parte, verdade. Mas há também claros ganhos, ao menos para aqueles que se situam em favor de uma sociedade diferente: Harvey tem se dedicado, com afinco, a divulgar um pensamento progressista para além dos muros da universidade, e seu poder de influência é inegavelmente benéfico para a luta por justiça social.

Daniel de Mello Sanfelici - USP 